\title{
SUPERFÍCIES DE EROSÃO NO QUADRILÁTERO FERRÍFERO, MINAS GERAIS*
}

\author{
GETÚLIO VARGAS BARBOSA**
}

\begin{abstract}
Erosion surfaces in an area of faulted and folded relief are defined and localized in the Quadrilatero Ferrifero. The usual problems in delimiting the erosion surfaces are described. As a criterion, erosion levels are defined as reliefs of between 4 and $10 \%$ and controlled by spacial continuity and structural conditions. In identifying the areas of conserved relief, clearly separated from the dissected reliefs, the median is used instead of the mean. With this method a solution for the "cimeiras" surfaces in the Serra do Caraça was achieved, where neotectonic upheavals occured. The distribution pattern of contour lines for one generation of surfaces differs fundamentally from that of other generations. By the distinction of these patterns, lower levels are defined which are already controlled by the structures of great folds, principally in the synclines. By way of patterns and medians, the grade of surface coalescence is determined. A hierarchy of morphoclimactic processes is defined by the great variety .of pediments with or without material. The formation of the erosive complexes of pediment-playas, elaborated independently and connected, is concluded in recent periods, by the opening of drainage and exorheism.
\end{abstract}

INTRODUÇÃO O Quadrilátero Ferrífero é conhecido por suas reservas de minério de ferro e por suas cidades históricas. Sua significação aumentou após o mapeamento de detalhe realizado por um convênio entre o Departamento Nacional de Produção Mineral e o United States Geological Survey, de 1946 a 1962. Este mapeamento dividiu a área em 47 quadrículas de dimensões diferentes, na escala de $1: 25.000$, totalizando cerca de $7.000 \mathrm{~km}^{2}$. Os relatórios sobre a Geologia foram feitos por grupos de quadrículas, muitas dessas publicadas em conjunto.

Para o presente trabalho foram consideradas 32 das 47 quadrículas mapeadas. Esta diminuição deve-se à falta de continuidade espacial devido a não publicação das quadrículas de São Gonçalo e Florália, que impediu a utilização das quadrículas de Monlevade e Rio Piracicaba. A de Itabira também não foi incluida. Isto define um espaço físico compreendido entre os paralelos de $19^{\circ} 48^{\prime} 5^{\prime \prime}$ até $20^{\circ} 35^{\prime} 45^{\prime \prime}$ e os meridianos de $43^{\circ} 22^{\prime} 45^{\prime \prime}$ até $44^{\circ} 30^{\prime} 00^{\prime \prime}$ W. Gr. Geometricamente, esta área fica ao sul de Belo Horizonte e inclui, no Quadrilátero Ferrífero, cidades como Ouro Preto, Mariana, Sabará, Caeté, Santa Bárbara, dentre outras. O rio São Francisco drena a maior párte da região por seus afluentes Paraopeba e Velhas. As nascentes de alguns formadores do Rio Doce, como o Ribeirão do Carmo, Piracicaba e Gualaxo, ocupam menor área na parte oriental.

O clima é do tipo tropical chuvoso com invernos secos, mas tais condições não se refletem diretamente nem nos solos nem na cobertura vegetal em decor- rência das alterações específicas de grandes conjuntos litológicos de metassedimentos. Os solos são freqüentemente rasos, ferruginizados e fortemente pedregosos. A vegetação, está representada por florestas densas, matas secas, cerrados e campos limpos.

As áreas de reflorestamento com eucaliptos aumentam rapidamente. As reservas de minério de ferro são muito grandes; e siderúrgicas foram montadas para aproveitar algumas dessas jazidas. Disto resultou uma densa rede viária que corta a região em quase todas as direções.

A bibliografia da área comporta mais de 1500 títulos e parte considerável desse número ocorreu após o mapeamento geológico na escala de $1: 25000$. Dorr II (1960) apresentou a primeira síntese da Geologia Regional com um mapa na escala de 1: 200000 . Com base neste conhecimento, Barbosa \& Rodrigues (1965) publicaram um estudo especificamente geomorfológico sobre toda a região. Tricart (1961) realizou, sobre um itinerário bem escolhido, uma análise geomorfológica enfatizando a morfogênese atual.

Os relatórios do Levantamento Geológico do Convênio DNPM/USGS trataram dos aspectos geomorfológicos apenas como introdução, mas levantaram alguns problemaś importantes. Os mapas geológicos das quadrículas foram significativos porque as Formações Superficiais de interesse econômico estão mapeados. Em 1969, Dorr II publicou um relatório final, onde os problemas geomorfológicos foram tra:tados mais profundamente. Posteriormente, apenas

* Trabalho realizado com auxílio do $\mathrm{CNPq}$.

** Instituto de Geociências da Universidade Federal de Minas Gerais - Cidade Universitária - Pampulha - 30.000 - Belo Horizonte - MG - Brasil. 
trabalhos de detalhes foram acrescentados à geomorfologia regional.

Como o Quadrilátero Ferrífero forma um conjunto de relevos altos, ele guardou algumas das mais antigas superfícies de erosão do Brasil. Conhecer esses aplainamentos tem interesse na medida em que, praticamente, todas as litologias foram truncadas pela erosão e muitas jazidas de enriquecimento supergệnico estão relacionados aos níveis de erosão. Eliminou-se, desde aí, o erro de se confundir superfícies estruturais com superfícies de erosão. As grandes estruturas dobradas estão agora em posição geomorfologicamente invertida, isto é, as anticlinais foram desmontadas e as sinclinais estão elevadas. Esta configuração geomorfológica permitiu que no interior e nas abas sinclinais algumas das mais antigas superfícies de erosão pudessem ser conservadas até hoje. Uma grande extensão de crostas ferruginosas (cerca de $100 \mathrm{~km}^{2}$ ) protegeu e preservou parte destas superfícies.

Por outro lado, principalmente a E e SE, conjuntos de blocos falhados guardaram, também, evidências de aplainamentos antigos. Para superar estas circunstâncias específicas houve a necessidade de se empregar técnicas de trabalho um pouco diferentes a fim de se alcançar o objetivo final de identificar essas superfícies de erosão.

MÉTODO A utilização de imagens de radar e fotografias de satélites, permitiu demonstrar que o relevo brasileiro pode ser nitidamente dividido em superfícies conservadas e áreas de dissecação. Nas escalas em que estes materiais são produzidos, 1:1000 000 e suas ampliações a $1: 400000$ e $1: 250000$, esta separação não é difícil, mas estas não são as escalas usuais dos estudos geomorfológicos, exceto na medida em que fornecem um grande quadro regional.

Muitos trabalhos já realizados no Brasil, com o objetivo de determinar as superfícies de erosão, utilizam uma técnica de determinar altitudes comuns ou altitudes médias de várias elevações e definir o aplainamento como um plano imaginário correspondente às altitudes determinadas. Essa técnica foi intensificada após a publicação do trabalho de King (1956), que determinou relevos extensamente aplainados $\mathrm{e}$ as áreas dissecadas, ambos de um mesmo ciclo de erosão.

O método usado por King tem alguns inconvenientes fundamentais quando não se dispõe de documentação cartográfica de qualidade, quando a determinação de campo é visual e quando a altimetria definidora de uma superfície de erosão é obtida por altímetro. King deixou, pelo próprio método, o hábito de se empilhar os níveis de erosão segundo planos paralelos à linha do horizonte. Este método é, assim, gerador de erros quando se trata, por exemplo, de um relevo muito dissecado, mas a margem de erro reduz-se quando se trata de superfícies de erosão muito extensas e conservadas. Este método elimina a possibili- dade de se detectar as superfícies em rampas ou tectonicamente deformadas.

O presente trabalho utiliza uma técnica diferente, partindo-se do princípio de que relevos conservados e dissecados não podem ser submetidos a um tratamento homogêneo ou a uma mesma técnica, já que representam estágios diferentes da evolução geomorfológica. O nível de conhecimento do relevo do Quadrilátero Ferrífero permite definir que as suas condicionantes litológicas e estruturais foram adequadas para manter. restos de velhas superfícies conservadas. A evolução geomorfológica da área possibilitou que uma drenagem recente penetrasse no interior do Quadrilátero Ferrífero e criasse relevos dissecados. Os dois tipos - aplainamentos herdados e dissecação recente - estão justapostos. O critério para separar as antigas superfícies de erosão dos relevos dissecados foi o grau de afastamento das curvas de nível. O identificador foram os relevos com declives de até $4 \%$, tomado como limite de escoamento das águas. Eventualmente esses declives chegaram até $10 \%$ quando contínuos aos de $4 \%$ e, claramente separados dos relevos dissecados, que se identificam pelo espaçamento muito pequeno das curvas de nível. Cada área identificada como resto de uma antiga superfície de erosão, só foi considerada quando estava separada de outra superfície por escarpamento nítido e funcional ou por um relevo dissecado. Identificadas essas áreas por uma escala de registro de declives, seus níveis altimétricos foram anotados e expressos, em resultado final, pela mediana. As áreas com essas características foram assinaladas em 32 folhas topográficas e depois controladas pelas correspondentes folhas geológicas. $\mathrm{O}$ controle diminuiu o número de medianas das folhas topográficas com a eliminação de patamares estruturais, falhamentos e pedimentos. As camadas horizontais, que poderiam ser fonte de erro, só foram encontradas em poucas áreas e em nenhuma delas correspondiam a uma superfície de erosão.

As medianas foram lançadas em uma maquete do Quadrilátero Ferrífero na escala aproximada de $1: 200000$, para se obter uma visão regional e tentar correlações entre os diferentes restos de superfícies. Nesse processo, o' número de medianas foi reduzido em função da escala.

Obtida a maquete com a distribuição das superfícies determinadas pelas medianas, foram realizados os trabalhos de campo na pesquisa de outros elementos indicadores, principalmente as formações superficiais correlaciona is aos aplainamentos. Com isto, o número de restos de superfícies de erosão foi reduzido a 91 , localizados em altitudes que variam de 834 a 2122 metros, uma descontinuidade muito grande. A redução do número de áreas consideradas como restos aplainados não significou sempre uma correspondente diminuição areal. Algumas delas forám unificadas quando a dissecação que as separava era insignificante, ea reconstituição do aplainamento herdado era segura. 
DISCUSSÃO DOS RESULTADOS As correlações dos dados, obtidos nas cartas topográficas e geológicas, nos trabalhos de campo e na maquete, indicaram a impossibilidade de se constatar níveis de aplainamentos regionais que pudessem ser seguramente mapeados e datados. O que se conseguiu foi a constatação de aplainamentos, posicionados em niveis, que são interpretados como fases erosivas diferentes e intercaladas por períodos de dissecação. Por outro lado, as condições naturais do Quadrilátero Ferrífero criaram compartimentos de relevo muito individualizados e a distribuição dos restos de aplainamentos esteve condicionada a estes compartimentos. Algumas tentativas de distribuir, estatisticamente, os 91 niveis deram resultados que contradiziam, nitidamente, as informações de campo e, tendiam a ser abstratos, numa pesquisa em que as condições geomorfológicas estavam sob controle. A solução encontrada foi acompanhar os níveis no campo usando indicações mais definidas, agrupando conjuntos e correlacionando-os a dados estruturais e materiais de cobertura, principalmente crostas ferruginosas. Foi conseguido ainda a identificação de "padrões de distribuição de curvas de nível", claramente discerniveis de acordo com cada resto de aplainamento. Os grupamentos conseguidos estão descritos a seguir.

SUPERFICIES CIMEIRAS Os mais altos níveis demarcados estão localizados no conjunto quartzítico da Serra do Caraça. Este conjunto abrange áreas das quadriculas de Catas Altas, Conceição do Rio Acima, Capanema e Santa Rita Durão. Neste maciço rochoso, entrecortado parcialmente por diques básicos já alterados, e constituído no todo por um conjunto de falhas de empurrão, foram detetados 12 medianas ou níveis. As medianas obtidas são altas, variam entre 1125 a $2122 \mathrm{~m}$. A observação das relações entre estes 12 níveis revelou inicialmente dois deles, cujos padrões de distribuição das curvas de nivel eram inteiramente diferenciados dos demais. Estes padrões característicos foram encontrados na Serra do Caraça propriamente dita, a $1886 \mathrm{~m}$ e o outro, confinado entre as serras com nomes locais de Casa Nova, Capivari e João Pinto, a 1879 m. A segunda revelação foi a de que os demais níveis da Serra do Caraça estavam relacionados às falhas de empurrão e apresentavam uma extensão muito menor que a dos níveis de $1886-1879 \mathrm{~m}$. Considerou-se estes dois níveis como o mais elevado resto de superfície de aplainamento do Quadrilátero Ferrífero. Os demais níveis podem ter sido relacionados a este e desnivelados posteriormente.

A possibilidade de uma neotectônica ter reativado o maciço do Caraça pode ser melhor discutida perante as demais medianas encontradas na Serra. A fragmentação muito abrupta, entre os restos de níveis cimeiros, é uma constante. Alguns destes níveis chegam até a borda de um declive muito forte, evidência de que eles foram cortados por uma erosão posterior que interrompeu uma superfície já pronta. Outros estão se-

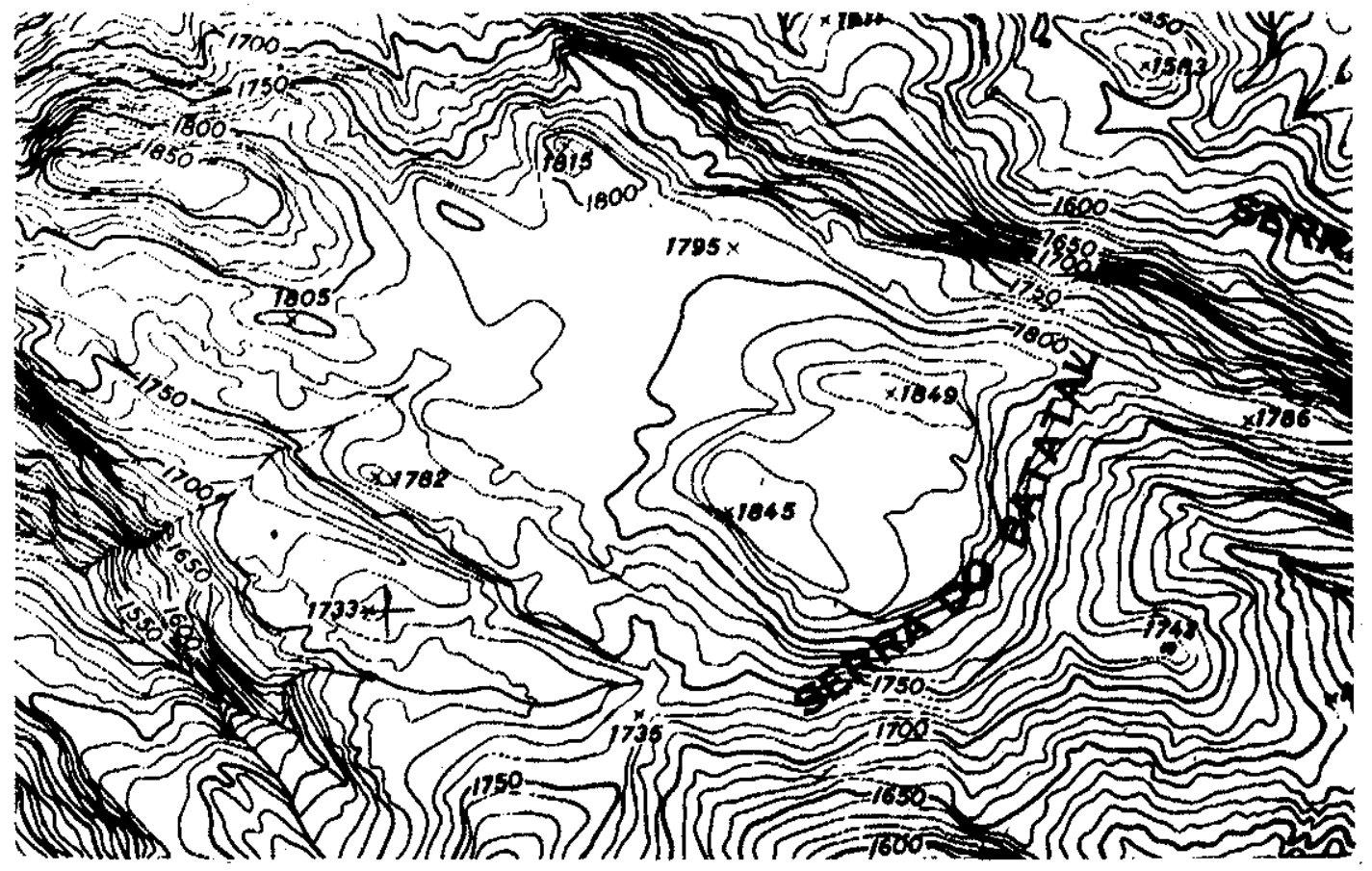

Figura 1 - Resíduo do complexo das superficies cimeiras do Quadrilátero Ferrifero na Serra do Batatal. Notar o padrão de curvas de nivel de residuo da superficie em contraste com as áreas de dissecação. A SW, parte de um patamar estrutural. A litologia das partes conservadas é do Grupo Itabira, parcialmente com crosta ferruginosa, quartzitos da Formação Moeda e Grupo Tamanduá. Notar a ausência de drenagem na área do resíduo. 


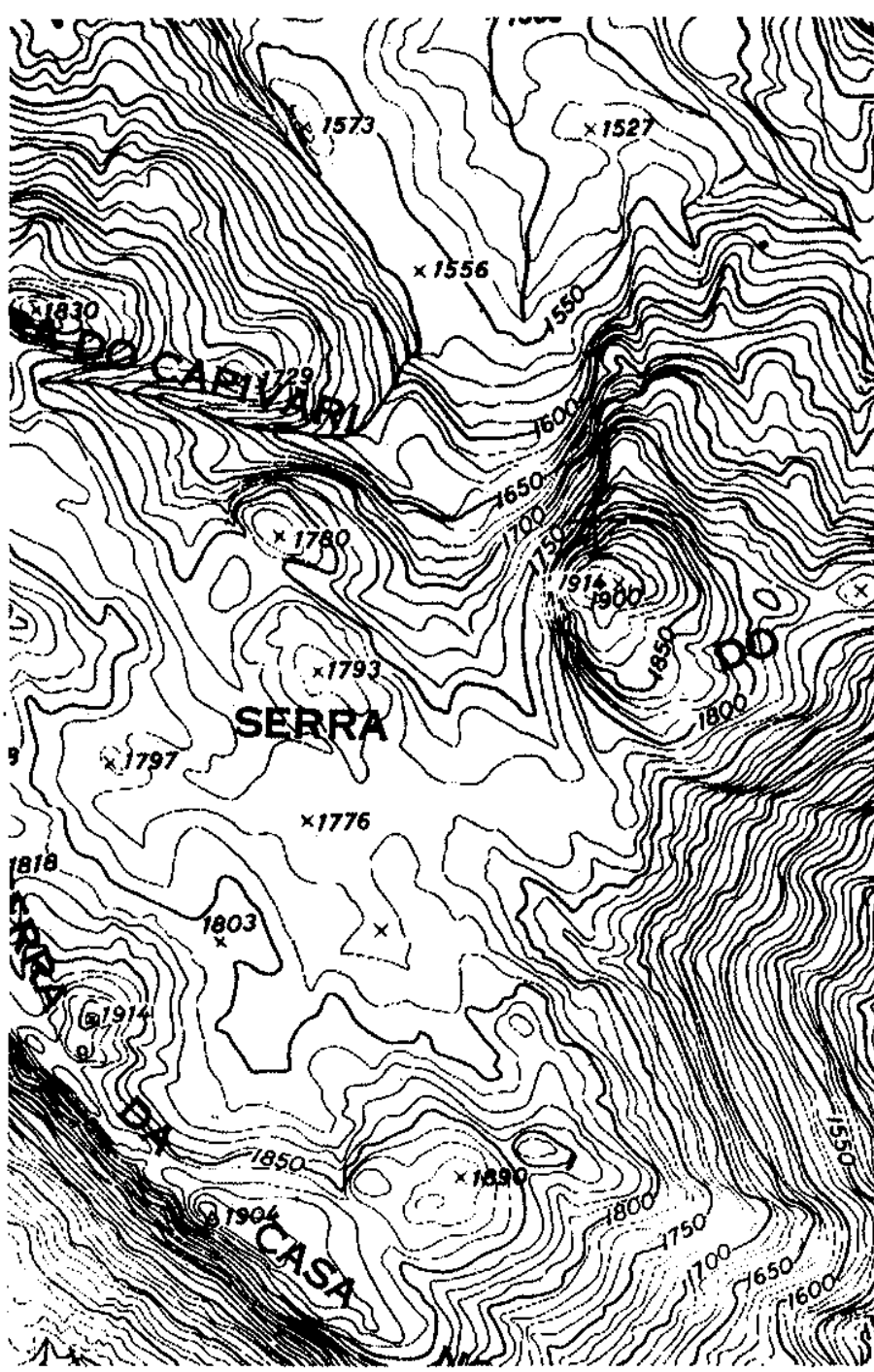

Figura 2 - Padrão de curvas de nível do complexo das superficies cimeiras na Serra do Coqueiro. Notar o arreismo total no relevo conservado. Na linha dada pelas cotas 1573 e 1556 há uma falha inferida. Notar a SW violenta ruptura de declive, sem falhas, no contacto Quartzitos do Grupo Tamanduá que forma todo o conjunto com os quartzitos do Grupo Maquiné.

parados por falhas de empurrão, com declives separando-os em blocos, sem que uma drenagem fosse, sequer, instalada em "vales" do tipo cañyon. Estes desnivelamentos separando dois níveis não são, portanto, erosivos. Eles estão relacionados a uma tectônica posterior à superfície de erosão que atuou sobre o conjunto da Serra do Caraça.

Harder \& Chamberlin (1951), que alcançaram estas elevadas e quase inacessíveis regiões, descrevem o material encontrado nos altos dos topos como fragmentos grosseiramente arredondados, mas não acrescentam maiores informações sobre o jazimento ou medições, para.que se pudesse depreender alguma conclusão sobre sua gênese.

Maxwel em comunicação escrita (1964) a Dorr II (1969) informa que, nos altos níveis, há material gros- seiro arredondado e fragmentos de rochas, mas também não acrescenta maiores informações sobre a gênese. De qualquer modo há indícios, além dos puramente topográficos, de que uma ou mais superfícies de erosão truncaram a Serra do Caraça, antes de sua reativação tectônica.

Almeida (1967) tem-se dedicado ao estudo das reativações tectônicas mais recentes. Ele definiu uma reativação iniciada no Jurássico Superior que pode ser a mesma que atingiu a Serra do Caraça. King (1956) coloca uma superfície única na Serra do Caraça como de idade Triássica ou Paleozóica. Não se tem a idade absoluta dos numerosos diques máficos que cortam parte da Serra do Caraça, porque o material está sempre alterado. Eles podem estar relacionados à reativação Wealdeniana de Almeida (1967), tal como ocorre em outras partes do Brasil. Entretanto, no Quadrilátero Ferrifero, não há nenhuma indicação geológica conhecida para a comprovação desta neotectônica. São válidos, portanto, os argumentos geomorfológicos.

As constatações são de restos preservados de uma superfície de aplainamento a $1886-1879 \mathrm{~m}$ e fragmentos desta ou de outro aplainamento no topo da Serra do Caraça. Estes aplainamentos são, em relação aos demais, seguramente mais antigos, mas não foram uma única superfície como sugere uma visualização afastada da serra, como fez King (1956).

Na procura de padrões característicos de curvas de nivel indicadoras de aplainamentos, foram encontrados outros níveis que caracterizam superfícies de erosão. É isto que ocorre na parte meridional do Quadrilátero Ferrífero, no Pico do Itacolomi. A E e W deste pico há duas áreas de distribuição de curvas de nível bem características. As medianas estão a 1647 e $1641 \mathrm{~m}$. Trata-se aqui, novamente, de restos bem preservados de uma superfície de erosão, com o Pico do Itacolomi funcionando como um inselberg. Estes restos guardam em comum com os da Serra do Caraça, o fato de se constituirem de quartzitos tectonicamente muito falhados. Esse conjunto de blocos falhados, de amplitude muito maior que na Serra do Caraça, faz o limite sul do Quadrilátero Ferrífero, em contacto com o embasamento granitóide. Todo o contacto é feito por falha, interessando as serras de Ouro Branco, Joẳo Ribeiro, do Pinto, do Salto $\mathrm{e}$ do Fundão.

Na Serra do Ouro Branco foi encontrado um nivel de $1450 \mathrm{~m}$, porém, sem todas as características das curvas de nível próximas ao Pico do Itacolomi. O topo é coberto por areias claras de alteração do quartzito, com nivel caindo para SE. É significativo o modo como ele é, abruptamente, interrompido por uma escarpa sem talvegues, que desce de 1450 até $1150 \mathrm{~m}$. Ùm extenso depósito de talus jaz no sopé da escarpa na Serra do Ouro Branco, o que é interpretado como reativação de escarpa. Nas Serras do Ribeiro e do Pinto, o nivel de 1557 é, também, bruscamente interrompido. Sobre a Serra do Fundão há um nível de $1050 \mathrm{~m}$. 


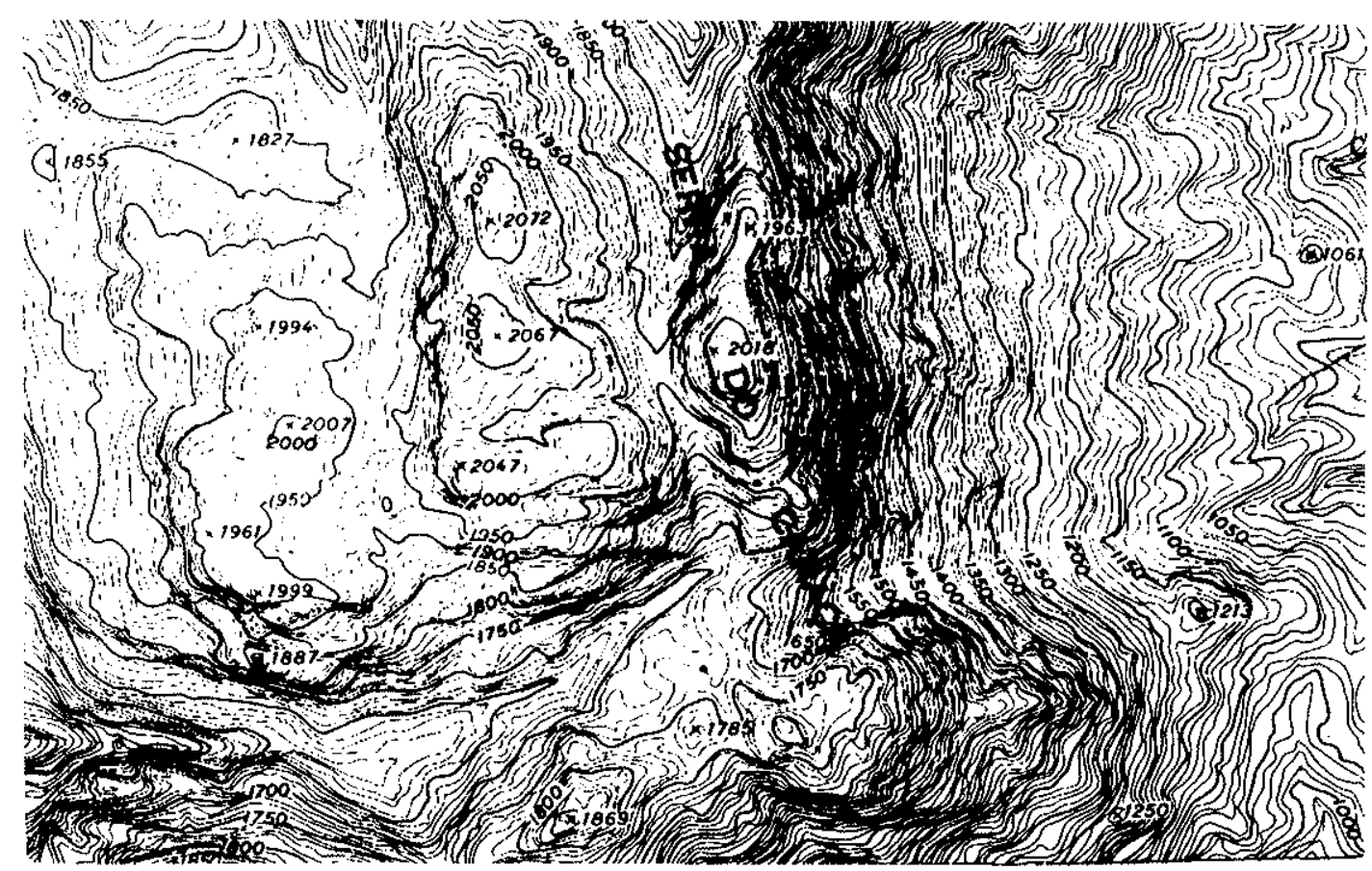

Figura 3 - Conjunto de blocos de falhas de empurrão na Serra do Caraça, dando restos de superficies cimeiras. Exceto uma drenagem que penetra pelo $\mathrm{N}$, no meio da foto, as outras escarpas são tectônicas reativadas posteriormente ao aplainamento. A litologia é toda em quartzito do Grupo Tamanduá. Notar a ausência geral da drenagem.

Em resumo, é presumivel que os desnivelamentos criados pelos falhamentos de empurrão tenham colocado um mesmo nível antigo em várias altimétricas diferenciadas e apenas os relativos ao Pico do Itacolomi e, parcialmente, o de $1450 \mathrm{~m}$ na Serra do Ouro Branco tenham sido mantidos bem preservados. É significativo, nesta área, o fato de as escarpas de falhas não apresentarem drenagem relevante caindo para o embasamento granitóide. A regra é a drenagem se deslocar para o sopé das escarpas uma indicação geomorfológica de falhas. Uma exceção, que precisa ser considerada, é a do Rio Acima que percorre o relevo dissecado do embasamento granitóide, em um nivel de aproximadamente $1000 \mathrm{~m}$, e depois abre uma garganta de superimposição nos quartzitos da Serra do Fundão e penetra dentro do Quadrilátero Ferrífero em forma de cañyon. Nestas circunstâncias, é muito sugestiva a idéia de que essa superimposição é bastante antiga e que foi formada em um tempo em que o Quadrilátero Ferrífero estava em nivel topográfico inferior ao do embasamento granitóide do sul. Pode-se tratar, também, de uma epigenia, do tipo antecedente à removimentação dos blocos falhados durante a reativação, mas não há evidências para permitir uma opção. De qualquer modo, as escarpas que limitam o Quadrilátero Ferrífero ao sul são, agora, escarpas de linha de falha.

Os níveis da seção sul, 1647 e $1641 \mathrm{~m}$ em torno do Pico do Itacolomi, o da Serra do Ouro Branco a

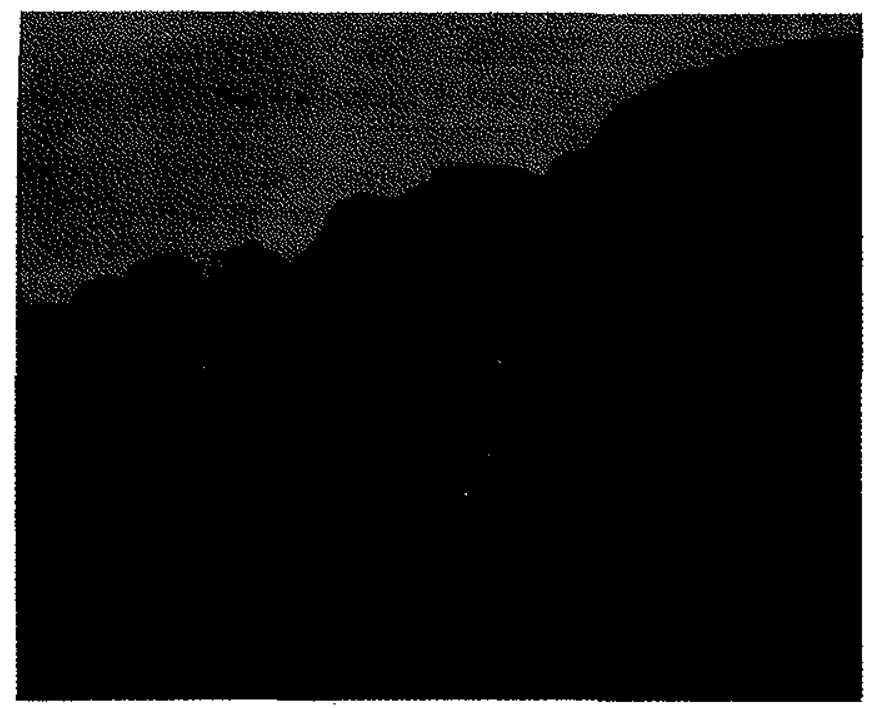

Figura 4 - Conjunto de blocos falhados e desnivelados em pedimentos estruturais confinados - Serra do Coqueiro.

$1450 \mathrm{~m}$, o da Serra dos Pintos a $1557 \mathrm{~m}$ e outros que a região apresenta, são considerados aqui como restos de uma superfície de erosão fragmentada. Ao contrário da Serra do Caraça, os níveis da parte sul foram mais preservados. ficando em posição mais elevada. As relações entre esses niveis e os da Serra do Caraça são praticamente impossíveis de serem estabelecidas. Há entre ambos outros níveis e relevos dissecados, 
além de uma distância muito grande. Além dos quartzitos, material em que os dois conjuntos de nível se formaram, do estilo tectônico em falhas de empurrão e dos diques, pode-se considerar ainda que esses níveis foram conservados nos lugares onde o estilo de dobramento em sinclinais e anticlinais predominante no Quadrilátero Ferrífero é mais raro. Essas duas áreas - Caraça e Itacolomi - guardam, assim, os mais antigos aplainamentos, e eles se formaram antes que as grandes anticlinais fossem totalmente esvasiadas, como se encontram agora.

\section{A SEGUNDA GERAÇÃO DE APLAINAMENTOS}

As grandes estruturas dobradas em sinclinais e anticlinais estão relacionadas com a última fase orogêniça que, no Quadrilátero Ferrífero, é marcada pelo granito de 550 M.A. O número de sinclinais é muito grande, mas as dimensões variam e, com elas, os efeitos geomorfológicos. As variações ocorrem também em função de falhamentos, como a grande falha do Fundão que perturbou a disposição normal da Sinclinal Gandarela. Por outro lado, as grandes sinclinais comportam alguns dobramentos menores.

Esta complexidade estrutural dificulta uma reconstituição dos dobramentos porque a aerosão atuou sobre eles. Barbosa \& Rodrigues (1965) tentam uma reconstituição desses dobramentos, com base na situação geomorfológica atual dos sinclinais suspensos e na distribuição dos metassedimentos da Série Minas. E evidente que a variação de espessuras das camadas da Série Minas, sua plasticidade e os falhamentos que afetaram essa série, dão à reconstituição um caráter hipotético, porém provável.

No interior do Quadrilátero Ferrífero, a erosão já expôs o Complexo do Bação, sobre o qual ainda restam pequenas manchas da Série Rio das Velhas. Ao S, E e W desse complexo e da Série Rio das Velhas, elevam-se sinclinais da Série Minas. A reconstituição feita pelos autores citados, sugere que a aba oriental da Sinclinal da Moeda, a aba Norte da Sinclinal Dom Bosco, as abas ocidentais das sinclinais de Conta História e Ouro Fino e o fundo da sinclinal Gandarela estiveram unidos sobre a área deprimida do arqueamento do Rio das Velhas. É, praticamente, impossível reconstituir a altitude e atitudes dessas camadas, exceto na anticlinal de Mariana, cujas abas de terminação estão próximas e contínuas.

Em torno do Maciço do Caraça as reconstituições são muito mais difíceis, porque a área é muito afetada por falhamentos. Igualmente dificil é a reconstituição do conjunto Sinclinal Gandarela-Anticlinal da Conceição, com as sinclinais da Alegria e os afloramentos que estão ao pé da Serra do Caraça. Uma reçonstituição exigiria uma cobertura da Série Minas passando sobre a Serra do Caraça. As possibilidades de unir, em constituição, a aba ocidental da Sinclinal Moeda com uma suposta sinclinal Serra da Piedade, referida por Simmons (1968), são mais remotas, porque ambas se adelgaçam e terminam nos complexos granitóides localizados a W do Quadrilátero.

Esta reconstituição interessa na medida em que toda uma estrutura de dobramentos foi desmontada, deixando as sinclinais geomorfologicamente suspensas. No interior dessas sinclinais, o enchimento dado pelo Grupo Piracicaba pode ter sido aplainado em fase posterior aos aplainamentos das abas. Por outro lado, as estruturas da base das sinclinais foram esculpidas em patamares rochosos, sucessivamente escalonados até os topos das abas.

Esses restos de relevo dobrado, raramente são largos e constituem cristas sustentadas pelos quartzitos do Grupo Moeda e pelos itabiritos do Grupo Itabira, dando um aspecto pseudo-apalacheano. É sobre essas cristas que se encontra uma segunda geração de superfícies de erosão dentro do Quadrilátero Ferrífero.

Com base nesta reconstituição do relevo, parece certo que as abas das grandes dobras em sinclinais foram aplainadas, após o esvaziamento das anticlinais. A inexistência de qualquer tipò de relevo residual ou de litologias diferentes, dentro das sinclinais, 'é indicativa de que as sinclinais nunca estiveram aplainadas de uma aba até outra. Por outro lado, não se pode dizer o mesmo dos dobramentos em anticlinais, pois aí restam alguns elementos altos e concordantes em altitude. Isto é constatado, por exemplo, na suposta anticlinal do Rio das Velhas, próximo a Nova Lima, onde há elevações a 1314 e $1315 \mathrm{~m}$. Entretanto, esse suposto nível está abaixo dos aplainamentos, seja das abas, seja do interior dos sinclinais. $\mathrm{O}$ mais significativo está próximo a Souzas, no Vale do Rio Paraopeba, onde um inselberg de $1298 \mathrm{~m}$, isolado dentro de um relevo dissecado, poderá ser correspondente ao nível do topo da Serra do Curral a $1290 \mathrm{~m}$. Supor que a erosão das anticlinais esteve em um estágio de baixa energia, apenas por. estes três exemplos, é uma hipótese sem maiores possibilidades de comprovação, porque estão separados, entre si, por niveis mais' altos. Todavia, é significativa a proximidade dos dois inselbergs em Nova Lima: 1314 e $1315 \mathrm{~m}$, principalmente porque os dois apresentam topos nivelados, truncando estruturas dobradas do Grupo do Riơ das Velhas.

A SERRA DO CURRAL Esta é a mais conspicua unidade morfológica do Quadrilátero Ferrífero. Ela se estende por mais de $80 \mathrm{~km}$, desde.as proximidades de Itaúna até a Serra da Piedade ao norte de Caeté, com os nomes locais de Serras da Mutuca, Rola Moça, Jangada, Três Irmãos, Itatiauçu, Azul, entre outras. A estrutura está alinhada de SW para NE, fazendo pequenas inflexões. Ela é muito ressaltada no relevo, porque toda a extensão de seu sopé está em contato direto com rochas mais tenras. Costa \& Romano (1976) interpretam esta estrutura como uma falha de empurrão. Dorr II (1969) considera-a como um contato normal invertido, e Simmons (1968) sugere uma 
estrutura em sinclinal, denominada Piedade. Sua posição altimétrica elevada foi mantida pelo Grupo Itabira, constituído por itabiritos, e pelo Grupo Caraça, formado principalmente por quartzitos.

De SW para NE; a Serra do Curral apresentou o seguinte conjunto de medianas: 1306 na Serra do Itatiauçu; 1209 na Serra dos Souzas; 1310 na Serra do Fecho do Funil; 1308 na Serra do Jangada; 1406 na Serra do Rola Moça; 1434 na Serra do Mutuca; 1274 na Serra do Curral; 1068 na Serra do Sabará e 1133 na Serra da Piedade. Isto dá uma variação das medianas desde 1068 até 1434 . Tais variações são explicadas ora por uma proteção de espessas crostas ferruginosas, ora pelo adelgaçamento da camada de itabirito. King (1956) identificou, com base nestas variações, as superfícies Gondwana e post-Gondwana em posição mais baixa que na Serra do Caraça. Todavia, as explicações dadas anteriormente para as diferentes variações da mediana e as gargantas de superimposição abertas pelos rios Paraopeba e Velhas, além da inexistência de quebra de continuidade, sugerem mais a existência de apenas um nível de erosão.

Em abono da concepção de King (1956), assinalese a existência de algumas gargantas do tipo Wind-gap e, principalmente, a ocorrência de um pedimento com sedimentos flúvio-lacustres que, saindo da Serra do Curral, dirige-se para o leste do sítio urbano de Belo Horizonte. Este pedimento isolado sugere que a Serra do Curral foi integrante de um aplainamento que se estenderia, em sua parte sul, ao nível de $1300 \mathrm{~m}$ e que coincide com o nível dos inselbergs de Nova Lima, já referidos, nas altitudes de 1314 e $1315 \mathrm{~m}$.

O Grupo Piracicaba, invertido em sua posição estratigráfica na Serra do Curral, origina patamares mais baixos no lado norte da Serra. King (1956) considerou esses patamares como restos da superfície Sul-Americana, mas o problema de patamares tem, dentro do Quadrilátero Ferrífero, uma significação diferente, como se verá mais adiante. Não fosse o gap aberto pelo Rio das Velhas, controlado por falhamento, poder-se-ia ter uma idéia das virgações que atingiram a Serra do Curral. Não há outra evidência de movimentação tectônica nesta serra, exceto as gargantas de superimposição, como a do Rio Paraopeba, próximo a Brumadinho. Não há indicação de que essa garganta tenha sido resultante de captura fluvial. Tudo indica uma antecedência do rio em relação à neotectônica. A observação dos padrões de curvas de nível, em Fecho do Funil, não indica uma paralisação da erosão.

A SERRA DA MOEDA A Serra da Moeda representa a aba ocidental da sinclinal do mesmo nome. Ela se estende de Norte para Sul, desde seu encaixe na estrutura da Serra do Curral até desaparecer sobre as rochas granitóides, próximo a Jeceaba. Sua extensão é de cerca de $60 \mathrm{~km}$.

A disposição litológica da Serra da Moeda é a mesma da Serra do Curral, porém em posição normal, isto é, os quartzitos do Grupo Caraça fazendo a base para os itabiritos do Grupo Itabira. O topo desta serra apresenta as medianas de $1367,1460,1509,1436$ e 1 146, distribuídas de $\mathrm{N}$ para $\mathrm{S}$. A mais elevada mediana, a de 1509 , corresponde à área de maior aproximação entre as abas oriental e ocidental. Um nível de $1518 \mathrm{~m}$ aparece separado do de 1434 por um escarpamento. Isto sugere a possibilidade de que o topo da Serra da Moeda tenha restos de mais de um nível, mas a existência de apenas uma mediana diferenciada é insuficientę para a confirmação do fato. Na Serra do Rola Moça (1 $406 \mathrm{~m}$ ), na Serra do Curral, este nível de aplainamento se prende, quase diretamente, ao nivel de 1367 , separado por Wind gaps com topos marginais nivelados e muito próximos. Desse modo, pode-se seguir, com continuidade comprovada, a superfície da Serra do Curral com a da Serra da Moeda.

Os niveis de aplainamento da Serra da Moeda estão dispostos com um centro dispersor a $1509 \mathrm{~m}$, mais ou menos no centro da estrutura e daí decaem para norte e para sul. A possibilidade de a Serra da Moeda ter sofrido ação de vários períodos de pediplanação, sugerida pela posição dos atuais restos de aplainamentos, não foi confirmada.

A ligação entre duas estruturas (Serra do Curral e Serra da Moeda), com niveis de aplainamento contínuo, ocorre próximo à Vargem dos Óculos na cabeceira do córrego do Tamanduá, indicando a possibilidade de ter havido um nível de aplainamento descontínuo não concluído, uma vez que é composto de pedimentos que se fundem em um lugar definido e geomorfologicamente importante. As variações dos níveis ao longo das duas estruturas têm explicações de ordem estrutural e litológica. Mesmo admitindo-se a existência de um pediplano contínuo, que unisse as duas serras, este não apresentaria um nível regular, pois as serras formam um nivel que decai nas áreas onde os pediplanos puderam instalar-se. Esta interpretação resulta da total falta de rupturas de declives funcionais entre os niveis assinalados na Serra do Curral e na Serra da Moeda.

A interpretação dos níveis contatados na Serra de Itabirito (regionalmente, Serra do Galinheiro, Trovões e Saboeiro) ajuda na reconstituição do relevo a partir de resíduos mais antigos de superfícies de erosão. A Serra do Itabirito representa a aba oriental da Sinclinal Moeda. Ela tem um relevo muito menos aplainado que a Serra da Moeda. Apenas 4 níveis foram assinalados: $1352,1452,1319$ e $1320 \mathrm{~m}$, com - $1 .^{\circ}$ e $2 .^{\circ}$ agrupados diferentemente do $3 .^{\circ}$ e $4 .^{\circ}$, distribuídos de acordo com a litologia do Grupo Caraça e Grupo Itabira. Além disto, há uma causa porque a Sinclinal da Moeda é dissimétrica e invertida, dando mergulhos diferentes nas Serras da Moeda e Itabirito. Esses quatro níveis são insuficientes para se tentar a reconstituição do relevo. O problema de supor que um mesmo aplainamento atingiu o topo da Serra da Moeda e o topo da Serra do Itabirito fica em aberto e com muito pequenas possibilidades de ser solucionado. 
Apenas na zọa terminal norte se percebe que o nível de 1367 , se incorpora à junção dos niveis da Serra do Curral e Serra da Moeda. Todavia, ao contrário das duas primeiras, na Serra do Itabirito um nível de erosão não pode ser ligado aos 4 níveis assinalados por falta de continuidade topográfica.

A sinclinal Moeda, representada pela Serra de Itabirito e Serra da Moeda; é uma das estruturas geológicas menos complicadas do Quadrilátero Ferrífero. Ele está dissecado em suas partes ocidentais, no Domo do Bonfim (Dorr II, 1969) e também, em suas partes orientais, onde ocorrem o complexo do Bação e o Arqueamento do Rio das Velhas.

Colocada em posição geomorfologicamente suspensa, a Sinclinal da Moeda pode preservar restos. de aplainamentos no seu interior. Essa área que Pomerene (1964) chamou de "Plateau da Moeda" tem bom acesso e a visão de conjunto dá a idéia de que o Grupo Piracicaba, que forma seu interior, foi aplainado e o desmonte do aplainamento ocorreu apenas após a instalação de uma drenagem maior, controlada pelo Ribeirão Mata Porcos. As pequenas drenagens que rompem as abas da sinclinal não foram suficientes para transformar o interior da Moeda em uma região dissecada. Na área há muitos elementos morfológicos e geológicos que podem ser tomados para esta discussão. Dentre estes estão bacias endorreicas, depositos de argila recentes, crostas ferruginosas e pedimentos. Dois destes elementos podem ser postos em destaque: os pedimentos e ás bacias endorreicas.
Os pedimentos são constatados ao longo de todo o dip-slope da Serra da Moeda, em sua parte voltada para o interior da sinclinal preenchida pelo Grupo Piracicaba. Eles existem também, ainda em dip-slope, na Serra do Itabirito: Como ficou constatado a relação dos níveis de erosão do topo da Sinclinal Moeda e do topo da Serra do Curral, os pedimentos desta estrutura também serão considerados. Aqui eles estão igualmente em dip-slope, mas em todos os três elementos estruturais eles ocorrem, também, sobre os frontes erosivos das çamadas. As manchas de pedimentos podem estar marcadas por crostas e concreções ferríferas, mas uma grande quantidade delas, a maioria, foi diretamente elaborada sobre as rochas, agora abertas sobre forma de leques, que Triccart (1961) chamou de "patas de elefantes". As mais importantes são aqueles pedimentos revestidos por material.

Nas estruturas das Serra da Moeda, Itabirito e Curral foram feitas medidas de declividade em, respectivamente, 9,4 e 17 pedimentos claramente discerniveis. A extensão maior da Serra do Curral, principalmente a circunstância de funcionar como uma crista entre relevos dissecados a norte e a sul, explica a preservação de um número maior de pedimentos que na Sinclinal Moeda. Estas medidas só foram feitas onde os pedimentos não estavam dissecados e a distribuição das curvas de nível fosse, de tal modo, diferente das dissecações posteriores, que pudesse oferecer uma credibilidade forte de que se tratavam de formas residuais, mais antigas. Igual-

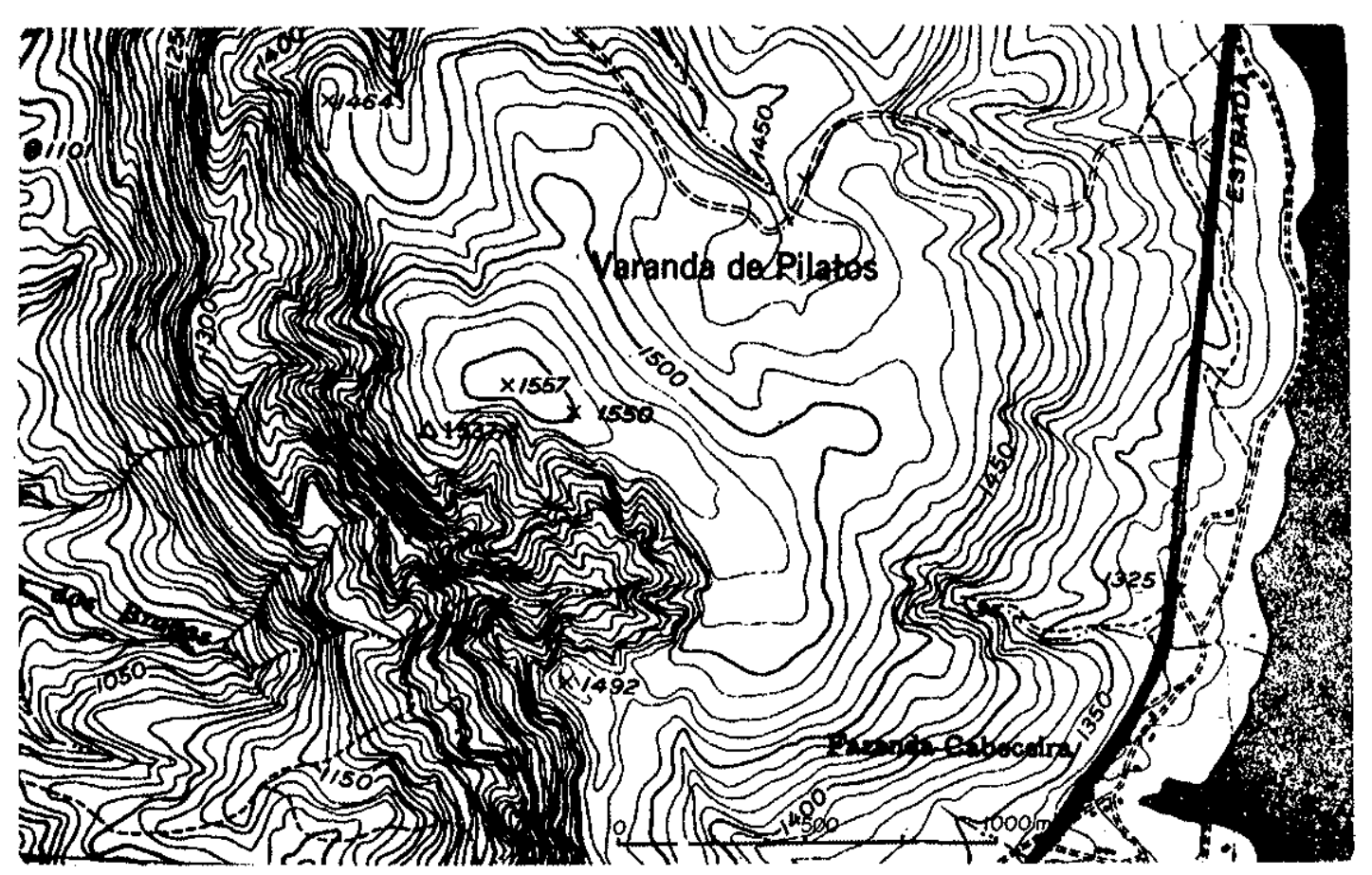

Figura 5 - Padrão de curvas de nível característico da segunda geração de superfícies de erosão. Notam-se a nítida separação entre relevos conservados a $E$ e relevos dissecados a $W$ e os pedimentos ravinados a $\mathrm{E}$. $\mathrm{A}$ dissecação a $\mathrm{W}$ marca a primeira fase de erosão do Holoceno e a de E assinala a segunda. 
mente, não foram consideradas as medidas em que os pedimentos coincidiam com os mergulhos das camadas.

$\mathrm{Na}$ Sinclinal da Moeda, os valores dos pedimentos foram os seguintes: 1,$3 ; 1,5 ; 2,6 ; 2,9 ; 3,0 ; 3,0 ; 4,2$; 7,5 e $7,7 \%$ e na Serra do Itabirito 1,$3 ; 1,3$ e $7,5 \%$.

Esses baixos valores, todos compreendidos entre os percentuais que se considerou aqui para as superfícies de erosão, indicam que o processo erosivo dentro da Sinclinal Moeda foi de pediplanação, que ocupou o fundo e as abas da sinclinal. São formas, portanto, nitidamente erosivas, porque truncam todas as litologias das abas. Vários desses pedimentos começam nos topos aplainados da Serra da Moeda e Itabirito e terminam no piso aplainado conservado ou pouco dissecado pelo Ribeirão Mata Porcos. No piso do pediplano da Moeda, o nível de erosão está a $1352 \mathrm{~m}$, caindo para o sul a $1270 \mathrm{~m}$ e elevando-se próximo a Casa de Pedra.

Esses pedimentos se ligam ao nível de aplainamento do piso da Sinclinal Moeda, e são um evento posterior ao aplainamento do topo das sinclinais. Ocorre, ainda, uma incisão forte do Córrego Mata Porcos que, em alguns pontos, já ataca as crostas ferruginosas. Em cortes abertos por mineração, pode-se perceber uma sequiência de material pedimentar variado truncando as litologias inalteradas. Este contato evidencia que o processo de deposição das sequiências coluviais foi realizado em um clima seco, incapaz de alterar o embasamento. Posteriormente, o clima passou a úmido com uma estação seca, pois foi capaz de criar sequiencias argilosas em meio a conglomerados cimentados por limonita. Estas informações indicam que os pedimentos foram retrabalhados várias vezes.

Na Sinclinal Moeda há numerosos depósitos contendo argilas mosqueadas ou avermelhadas. Uma parte destas argilas está relacionada com a formação de dolinas cársticas, abertas nos dolomitos da Formação Gandarela. Na jazida Vargem dos Óculos, os furos de sondagens mostraram a existência, entre argilas e os dolomitos da Formação Gandarela, de uma crosta limonítica contínua com 11 a $12 \mathrm{~mm}$ de espessura. Esta crosta indica clima com duas estações. Um clima mais úmido posterior é responsável pelo preenchimento das dolinas. Nas fases de pediplanação e pedimentação estas colinas funcionaram como pequenas bajadas, recolhendo argilas. Algumas delas foram tamponadas por crostas e posteriormente receberam novos sedimentos coluviais. Foram criados, assim, pequenos compartimentos isolados com o pedimento e a bajada, como parece ser o caso do sopé do Pico de Itabirito, dentre outros. Estes conjuntos estão em altitudes um pouco diferenciadas entre si, e só a abertura da drenagem pelos ribeirões Mata Porcos e Rio do Peixe deu uma certa unidade ao piso da. Sinclinal. King (1956) considerou uma destas $b a$ jadas, a da Lagoa Seca na Serra do Curral, como superfície Sul-Americana. A abertura da drenagem foi responsável pela migração do ferro e a transformação das argilas em bauxita, como parece ter sido o caso da Vargem dos Óculos. Em outros casos, a dissecação atingiu as rochas da estrutura da Sinclinal deixando os depósitos argilosos topograficamente elevados. Este é o caso do depósito próximo à Lagoa da Codorna.

SINCLINAL GANDARELA Tanto na Sinclinal Moeda como na Sinclinal Gandarela, a erosão foi, até certo ponto, controlada pela estrutura. A forma desta sinclinal é bem diferente, pois a terminação é muito mais larga que seu fechamento. Além disto, a Falha do Fundão - a mais extensa do Quadrilátero Ferrífero - perturbou a estrutura da Sinclinal Gandarela. De modo geral, pode-se dizer que os níveis de erosão das abas desta sinclinal decaem para NE desde um topo mais alto a $1600 \mathrm{~m}$, geralmente recoberio por crostas ferruginosas.

A sinclinal se estende desde a Serra do Lopes, passando pela Serra do Maquiné, do Gandarela, de Água Limpa, Morro Redondo, Palmital e Serra do Bento. Tanto nestas serrás como nas abas da sinclinal, a erosão atuou profundamente, deixando apenas pequenos trechos de aplainamento. Em quase toda sua extensão, as abas NW e SE da Sinclinal estão protegidas por crostas ferruginosas, expondo o Grupo Itabira a uma profunda dissecação controlada pelo Rio Socorro. Acompanhando as duas abas, o nível de 1600 decai na aba NW para 1382 e 1150 e na aba SE ele decai para 1284,1056 e 1000 . Todos esses níveis estão marcados por crostas, que aqui exercem um influente papel na preservação dos níveis de aplainamentos antigos com uma cobertura contínua. A parte SE da Sinclinal Gandarela é ocupada pela Anticlinal Conceição, que é marcada pelo Córrego da Conceição, acompanhando o eixo da estrutura. Esta anticlinal está em processo de total inversão geomorfológica, o que faz com que a Sinclinal Gandarela se mostre suspensa, principalmente devido à proteção das crostas ferruginosas. Geralmente, se considera que as crostas ferruginosas do Quadrilátero Ferrifero são materiais correlativos aos niveis de erosão. Entretanto, a observação de campo revela que isto nem sempre é verdadeiro. Assim, o extenso recobrimento de crostas, na Serra do Rola Moça, mostra a limonitização direta do itabirito, recoberto por seixos de até $20 \mathrm{~cm}$, de canga rolada em regime torrencial sobre a qual ocorre $1 \mathrm{~m}$ de colúvio com concreções pisolíticas de limonita, mostrando um processo de enriquecimento autigênico recoberto por processos alogênicos.

Um dos acessos mais utilizados para se atingir a Sinclinal Gandarela e outras estruturas análogas, como a Sinclinal Ouro Fino e a do Conta História, se dá a partir da cidade de Itabirito. Este percurso é feito por uma série de patamares estruturais, com lito- 


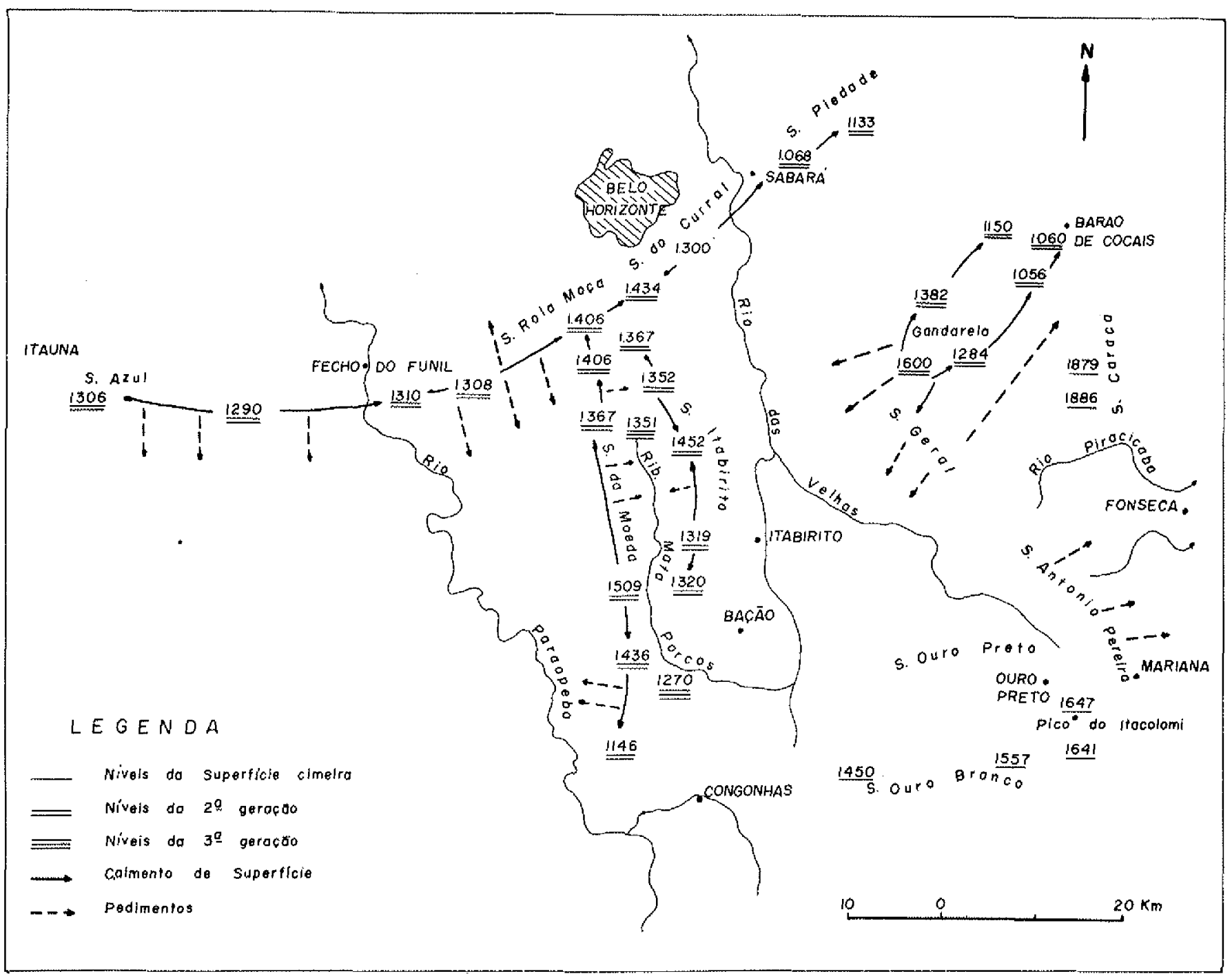

Figura 6 - Esboço do Quadrilátero Ferrífero mostrando a distribuição dos niveis de erosão

logias do Grupo Rio das Velhas, cujos dobramentos são de SE para NW, quase paralelos, portanto, aos da Série Minas. Localizados na vertente do Rio das Velhas, esšes patamares estruturais são largos, de 300-400 metros, e bastante continuos. Eles criam um contraste muito nítido com as escarpas e o nivel de erosão quase intacto da Série Minas, que está acima deles. No acesso à Sinclinal Gandarela há patamares a $1206,1353,1450 \mathrm{~m}$; no acesso à Sinclinal Ouro Fino, só há um patamar a $1085 \mathrm{e}$, no acesso à Conta História, ele está a $1346 \mathrm{~m}$. As inúmeras nascentes de rios atestam que, apesar de mais ou menos contínuos, estes níveis não são níveis de erosão. Os padrões de curvas de nivel superam muito os estabelecidos neste trabalho. São exemplos de rampas de colúvio controladas pela litologia. A exemplo dos patamares do norte da Serra do Curral, também estas rampas estão cortadas pela drenagem de $1{ }^{a}$ ordem. Esses patamares estão esculpidos em litologias pouco alteradas, com colúvios abundante e uma stone-line superficial.

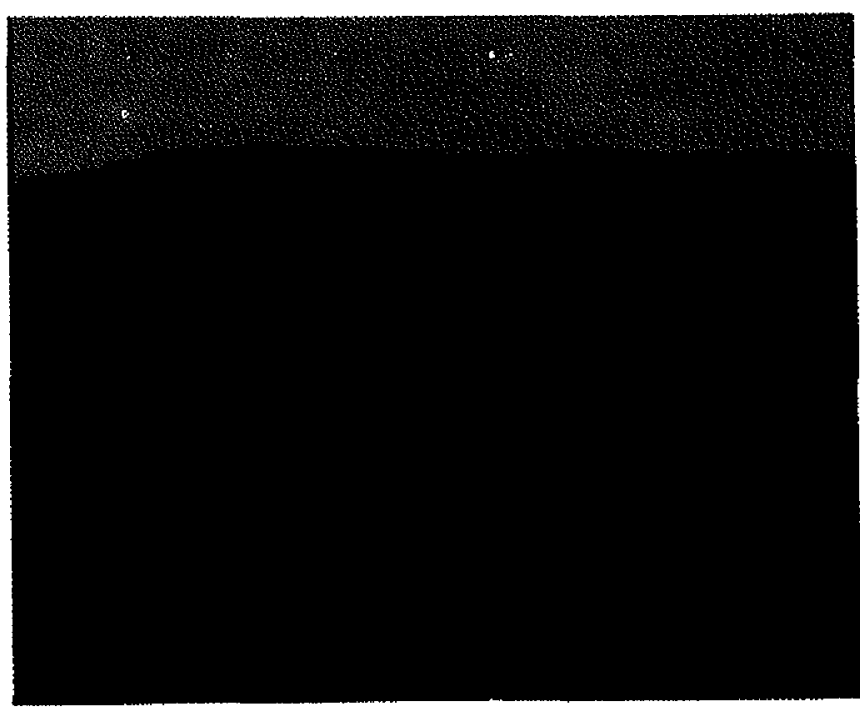

Figura 7 - Três níveis de patamares estruturais, claramente pedimentados e compartimentados. $\mathrm{O}$ topo mais alto mostra vestígios da segunda geração das superficies de aplainamento - Serra Geral. 
OS PERÍODOS DE DISSECAÇÃo Os poucos niveis de erosão que puderam ser analisados são relitos de superficies mais antigas e conservadas por circunstâncias diferentes, principalmente pelos concrecionamentos ferruginosos ou litologias especiais. $\mathrm{Na}$ maior parte do Quadrilátero Ferrífero, predomina uma dissecação generalizada. A observação de campo, e análise da documentação disponível; permitem determinar alguns dos períodos de dissecação.

A disposição das curvas de nível, nos quatro res. tos conservados mais antigos, indica que eles se formaram em períodos secos, desde que estão sem drenagem ou desintegrados da drenagem atual. As informações de Maxwell (1964) e Harder \& Chamberlin (1951), sobre a existência de seixos grosseiros e arredondados na Serra do Caraça, são insuficientes para determinar se eles representam um material de drenagem antiga ou moderna.

A gênese do complexo das superficies cimeiras, fraturado, poderá ser melhor definido com a indicação precisa desses seixos. Após a elaboração do complexo das superficies cimeiras ocorreu um período de alta energia na erosão, que culminou com a elaboração da segunda geração, a das abas das sinclinais. Esse período terminou com um clima em que se manifestava uma estação chuvosa predominante e uma estação seca. Estas condições são necessárias para o concrecionamento de muitos detritos soltos, que estão colocados no topo dessa superfície. Este parece ser o primeiro evento de concrecionamento do Quadrilátero Ferrífero, porém não o único, pois há crostas antigas cimentadas por outra mais nova.

A erosão recrudesce na fase de elaboração dos pedimentos da Serra do Curral e no sopé do hog's back da Serra do Curral, com periodos secos iniciais, para elaborar a pedimentação e criar condições para abertura e posterior enchimento das dolinas da Formação Gandarela. Essa fase parece ter sido intercalada com estiagem longa, porque ocorre uma quantidade muito grande de fragmentos soltos ou concrecionados, intercalados com argilas nas terminações dos pedimentos. Muitos conjuntos pedimento-bajadas ficaram estanques desde a elaboração do nível do piso da Sinclinal Moeda.

A dissecação atual ou sub-atual, tem duas fases distintas. A primeira delas foi generalizada e abrangeu quase todos os setores do Quadrilátero Ferrífero, deixando a salvo apenas alguns trechos do conjunto pedimento-bajadas na Sinclinal Moeda e alguns restos dos mais altos complexos de superficies. A erosão chegou a um nivel de baixa energia, quando deixou níveis de cascalhos a 20/30 metros acima dos leitos dos rios Macacos, Piracicaba e Velhas, entre outros.

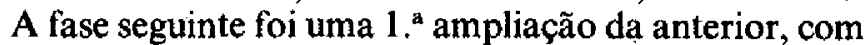
a drenagem de $1 .{ }^{8}$ ordem abrindo zonas anteriormente endorreicas por talvegues forçados, como os trechos de meandros encaixados do Rio das Velhas, e deixando planícies aluvionais e alvéolos nas áreas dos complexos granitóides. Esta é a erosão atual. Christofoletti \& Tavares (1976), afirmaram que esta erosão ocorreu em um período de clima quente e úmido. King (1956) assinalou a captura do Ribeirão Mata Porcos pelo Ribeirão Carioca, apenas por sugestão dada pela grande curva feita pelo Mata Porcos ao $\mathbf{N}$ de Congonhas. Este evento não pode ser confirmado, como ocorreu no caso da captura do Ribeirão Saboeiro pelo Ribeirão Carioca, próximo a Itabirito. As gargantes de superimposição de drenagem antecedente mostram uma parada do entalhamento, como nos rios Piracicaba, Carmo e Gualaxo. Esta fase de remarcação da dissecação parece corresponder à época de muitas capturas e desvios de cursos, a julgar pelas

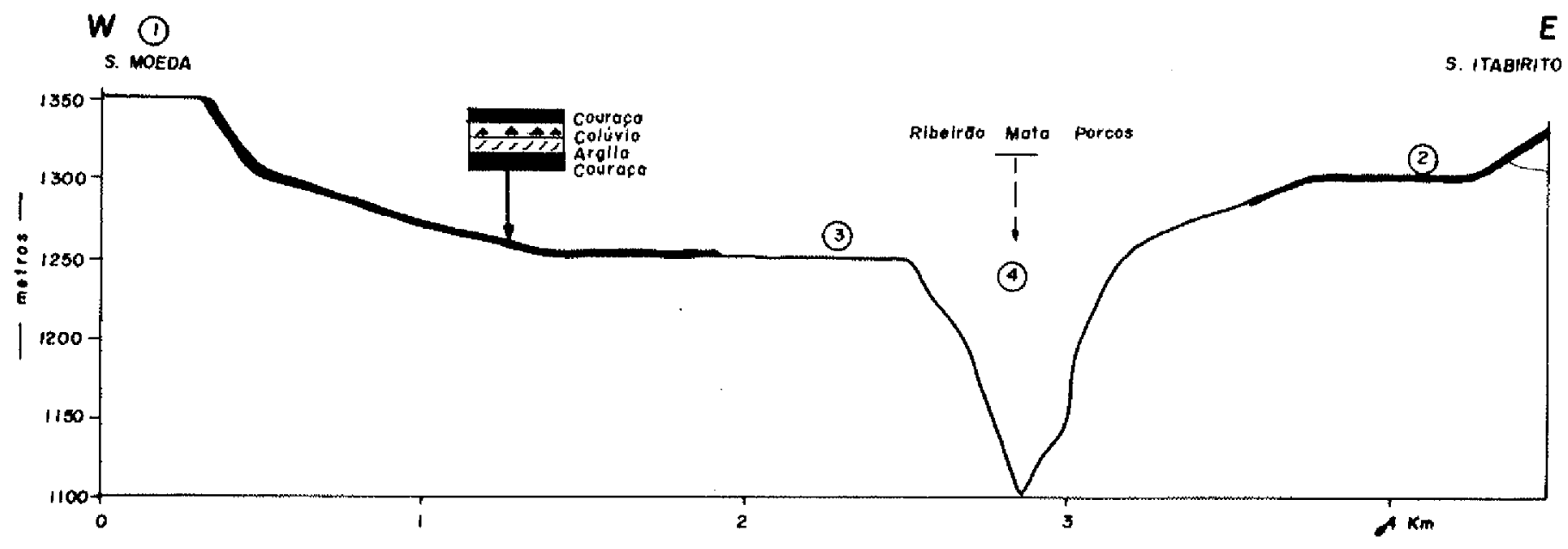

Figura 8-Perfil através da Sinclinal Moeda - mostrando a segunda geração de aplainamento na Serra da Moeda (1), os níveis de pedimentos com as linhas reforçadas (2), a superficie do piso sem cobertura de couraça (3) e a incisão da drenagem holocênica (4). 
bruscas inflexões de numerosos cursos d'água e Windgap, como ocorre na Serra do Rola Moça, Curral e outras.

Algumas elevações residuais, com topos planos isolados em meio a uma dissecação generalizada, sugerem outras fases de baixa energia erosiva. Os melhores exemlos são o Morro do Frazão (1 350) ao N de Antônio Pereira, Morro do Pires (1 $375 \mathrm{~m}$ ) a W de Honório Bicalho, Morro dos Cristais (1 $182 \mathrm{~m}$ ) na cidade de Nova Lima, entre outros. Uma tentativa de relacionar estes inselbergs com os níveis de erosão resultou infrutífera, mas de qualquer modo eles representam fases de dissecação bem marcadas.

Sobre os generalizados relevos dissecados do Vale do Paraopeba, ergue-se a crista da Serra do Curral, ostentando bem preservados níveis de erosão. Nas serras com nomes locais de Jangada, Três Irmãos e Fecho do Funil, no Vale do Rio Paraopeba, ocorrem numerosos pedimentos, isolados um dos outros pela fase atual de erosão. Esses restos de pedimentos estão situados no dip-slope da estrutura da crista dissimétrica e jazem sobre gnaisses e granitos. Resultam, pois, de detritos ferruginosos oriundos dos itabiritos do Grupo Itabira e foram cimentados. O mais extenso deles tem $3025 \mathrm{~m}$ e o mais curto $1675 \mathrm{~m}$. Medições feitas nos seis exemplos mais significativos indicaram $3,4 \% ; 6 \% ; 3,1 \% ; 4 \% ; 2 \%$ e $2 \%$. Como a Serra do Curral é aqui uma crista monoclinal bastante estreita, estes pedimentos são exemplos bem diferentes dos que estão confinados no interior da Sinclinal Moeda. Eles representam um período muito agressivo de erosão, pois todos eles são constituídos de material grosseiro (até matação). São colúvios de hematita e itabirito, eventuaimente cimentados por limonita ou misturados a colúvios menores ou solos. O período inicial se fez em ambiente muito torrencial e a limonitização em um clima a duas estações. A extensão deste pedimento, indo até cerca de 50 metros da drenagem atual e sua feição inferior truncada pela drenagem, indica que eles se formaram em uma fase climática posterior à primeira fase de dissecação e anterior à fase atual. Portanto, trata-se de uma fase de couraçamento bem recente.

Muitos dos autores que pesquisaram a região estão propensos a admitir apenas uma fase de encouraçamento, mas tudo indica que houve mais de um período e que ela ainda se forma. Barbosa \& Rodrigues (1965) mostram blocos grosseiros deslocados para uma barragem e que foram concrecionados após o represamento das águas, na década de 1930. Fragmentos de canga recimentados em outra crosta não são incomuns. Apesar de seu papel protetor da topografia e de uma extensão avaliada em $100 \mathrm{~km}^{2}$ dentro do Quadrilátero Ferrífero, as cangas estão sendo rapidamente erodidas. Os processos variam de sufusão, quando eles acompanham a topografia como em Marinho da Serra, até uma evolução por erosão diferencial quando ela preserva níveis de erosão, como na Serra do Rola Moça e até mesmo por aberturas de caneluras de escoamento quando a couraça é mais lisa, como ocorre na Varanda de Pilatos na Serra da Moeda. Em alguns lugares, a cobertura de crosta recobriu toda a superficie de erosão, deixando parte dela sem proteção. Isto sugere que não se pode tomar a formação das crostas como simultâneas ao processo de pediplanação. Verificações de campo revelam que as crostas revestiram superficies incompletas, dandolhes um aspecto regular e sugerindo que as próprias crostas foram atingidas por aplainamentos posteriores.

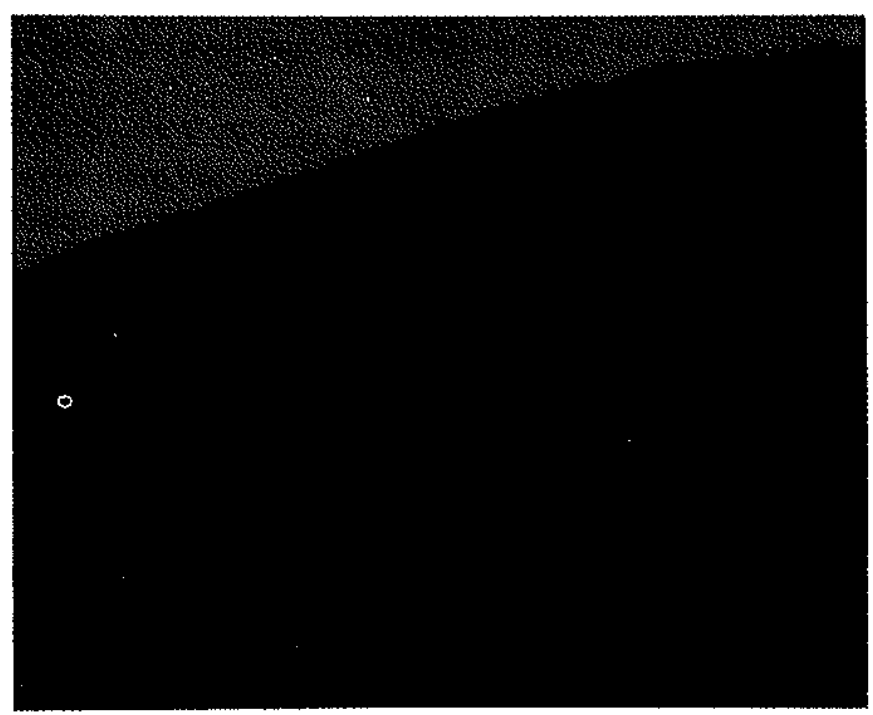

Figura 9-Pedimentos com concreções ferruginosas e conglomeráticas, vendo-se mecanismo de ataque por erosão diferencial - Serra do Saboeiro.

PROBLEMAS DE CRONOLOGIA A datação de eventos geomorfológicos dentro do Quadrilátero Ferrífero é bastante complicada. A dificuldade inicial resulta do fato de esta região estar praticamente separada de qualquer área onde haja algum fato geomorfológico já datado. $O$ uso de projeções de superfícies de aplainamento utilizado por King (1956), permitiu que ele trouxesse, desde as proximidades de Três Marias até o Quadrilátero Ferrífero, a superficie Gondwana e a partir dela as demais foram datadas. $O$ método é susceptivel de erro e por isto foi evitado no presente trabalho, mesmo porque nada acrescentaria ao que foi conseguido por King.

Em trếs pontos do Quadrilátero Ferrífero foram encontrados fósseis. Os mais antigos se referem às Bacias do Fonseca e Gandarela, que contêm níveis de linhito. Duarte (1958) identificou folhas da espécie Oxandra Emygdiana, dicotiledônea, atribuindo uma idade pliocênica à Bacia do Fonseca. Gorceix (1884) identificou a Bacia do Fonseca com datações entre. o Plioceno e Mioceno Superior. Sommers, em comunicação escrita a Dorr II (1969), afirma uma idade do Terciário Superior. Na Lagoa do Miguelão, na Sinclinal Moeda, Pomerene (1964) identificou um molde de folha impressa em argilitos como sendo do Terciário. 
A situação estruturalmente complicada e sujeita a interpretações muito divergentes, impede de considerar as folhas moldadas nos linhitos da bacia do Gandarela como um dado de confiança. De qualquer modo, os dados paleontológicos são muito vagos para serem correlacionáveis aos eventos geomorfológicos. As três localidades fossiliferas são geomorfologicamente muito diferentes e apenas uma delas, a da Bacia do Fonseca, corresponde a um nivel nítido de erosão.

Esta bacia está situada a E da Serra do Caraça, próximo à localidade de Fonseca. Segundo Dorr II (1969), a unidade estratigráfica - Formação Fonseca tem cerca de $85 \mathrm{~m}$ de espessura, contendo $7 \mathrm{~m}$ de seixos de granito, gnaisse, filito e quartzo na base, recoberta por arenito, argila e siltito até $27 \mathrm{~m}$. Lentes de linhito ocorrem em espessuras de $2 \mathrm{~cm}$, e outras rochas podem aparecer. Ainda, segundo Dorr II (1969), o topo é plano e a base, uma superficie de erosão terciária. $O$ depósito apresenta assim uma fase fluvial inicial, seguida de uma fase lacustrina, tamponada por concreções ferruginosas. A posição geográfica, defronte ao vão aberto nos quartzitos do maciço do Caraça, não indica que esta bacia é resultante de acumulação de detritos oriundos apenas do. Quadrilátero Ferrífero e trazidos pelo Rio Piracicaba. A presença de seixos de granito e gnaisse ao lado dos filitos e quartzo indica um enchimento com mais de uma área-fonte, já que, dentro do Quadrilátero Ferrífero, algumas dessas rochas estão fora da área de drenagem da bacia.

Desse modo, a bacia teve sua área-fonte independente do Quadrilátero Ferrífero. A afirmação de Dorr II (1969), de que a base é uma superficie de erosão Terciária, dificulta muito uma interpretação da morfogênese na área da Bacia, porque sinais deste nível de $-85 \mathrm{~m}$ não são encontrados na área, onde os saprolitos não chegam a ter esta espessura. Parece mais de acordo com a observação de campo, a elaboração de uma pequena depressão intermontana, que ficaria mais condizente com o tipo de preenchimento. Hoje ocorre sobre as crostas do Planalto da Canga uma superficie de $914 \mathrm{~m}, 876 \mathrm{~m}, 862 \mathrm{~m}$, demonstrativa da fase de erosão mais agressiva, que revestiu toda a Formação Fonseca com detritos de várias naturezas, cimentadas posteriormente. A preservação dos seixos de granitos indica que o tamponamento ferruginoso ocorreu logo após o enchimento da bacia. Essa crosta está nos níveis citados e com pedimentos de material torrencial das Serras do Caraça e Conta História. Pode-se supor que este nível é datáyel como Plioceno. Esta idade parece relacionar-se a outras bacias e depósitos cenozóicos do Brasil, como a Série Barreiras, por exemplo. Esta datação não ajuda muito na datação dos outros níveis, pois a bacia do Fonseca está localizada ao pé do Caraça, que guarda os níveis mais antigos. Talvez se possa datar outros depósitos no interior do Quadrilátero Ferrífero como desta fase, entre eles o preenchimento das dolinas da Formação Gandarela. Os depósitos de enchimento de vales na Serra do Curral e os pedimentos de material grosseiro da Serra do Curral, no vale do Paraopeba, são indicadores de uma fase muito agressiva de erosão com paralisação brusca. Eles estão em contato com relevos dissecados, aproximadamente do tipo que ocorre em torno da Bacia do Fonseca. Como, exceto para a Bacia do Fonseca e sua situação particular, os fósseis encontrados dentro do Quadrilátero Ferrífero de idade pliocênica, estão, seja na Bacia do Gandarela, seja na Lagoa do Miguelão, em áreas profundamente dissecadas, são de pouco valor para datar os relevos conservados. Portanto, projeções destas datações são apenas hipotéticas, o que deixa em aberto os problemas de cronologia dos eventos geomorfológicos dentro do Quadrilátero Ferrífero.

\section{BIBLIOGRAFIA}

ALMEIDA, F.F.M. de - 1967 - Origem e Evolução da Plataforma Brasileira. Bol. Div. Geol. Miner., DNPM. (241) $36 \mathrm{pp}$.

BARBOSA, G.V. e RODRIGUES, D.M.S. - 1965 - O Quadrilatero Ferrifero e seus problemas geomorfológicos. Bol. Mineiro de Geografia. $6(10-11): 3-35$.

CHRISTOFOLETT, A. e TAVARES, A.C. - 1976 - Análises de perfis de vertentes esculpidas em rochas do Grupo Nova Lima (Quadrilátero Ferrifero, Minas Gerais). Notícias Geomorfológicas, 16 (31): 41.56 .

COSTA, M.T. e RoMANO, A.W. - 1976 - Mapa Geológico do Estado de Minas Gerais - Instituto de Geociências Aplicadas -- Esc. $1: 1000.000$.

DOOR II, J.V.N. - 1961 - Esboço Geológico do Quadrilátero Ferrifero, Minas Gerais. Brasil. Pub. Esp. DNPM (1) 120 pp.

DOUR II, J.V.N. - 1969 - Physiographie stratigraphic and structural development of the Quadritatero Ferrifero, Minas Gerais, Brasil. U.S. Geol. Survey, Profs Paper (641-A): $110 \mathrm{pp}$.

DUARTE, L. - 1958 - Ammonaceae fóssess da Bacia Terciária de Fonseca, Minas Gerais. Bol. Div. Geol. Miner., DNPM, (178): 7-32.
GORCEIX. H. - 1884 - Bacias Tercrárias d'água doce nos arredores de Ouro Preto (Gandaréla e Fonseca) Minas Gerais, Brasil. An. Escola Minas de Ouro Preto (3): 75-92.

HARDER, E.C. e CHAMBERLIN, R.T - 1951 - A Geologı da Região Central de Minas Gerais. Bol. Geogr. do Cons. Nacional Geogr. (101): $492.544 \mathrm{pp}$.

KING, L.C. - 1956 - A Geomorfologia do Brasil Oriental - Rev. Bras. Geogr. 18 (2): 147.265 pp.

MAXWELL, C.H. - 1972 - Geology and ore deposits of the Alegria District, Minas Gerais, Brasil. U.S. Geol, Survey, Profs. Paper, (341 J) $70 \mathrm{pp}$.

POMERENE, J.B. - 1964 - Geology and ore deposits of the Belo Horjzonte, Ibirité and Macacos quadrangles, Minas Gerais, Brasil - U.S. Geol. Survey, Profs. Paper (341 D) $84 \mathrm{pp}$.

SIMMONS, G.C. - 1968 - Geology and iron deposits of the western Serra do Curral, Minas Gerais, Brasil. U.S. Geol. Survey Profs. Paper' (341 G) $57 \mathrm{pp}$.

TRICART, J. - 1961 - Le modelé du Quadrilátero Ferrifero au S de Bel. Horizonte, Brésil - Ann. de Géogr. (379): 255-272 pp.

Recebido em 4 de dezembro de 1978. 